\title{
Practical Activities for Cognitive Stimulation of Turner Girls, Teenagers and Women: A Guide for Themselves and their Families
}

\author{
Fátima do Carmo Fonseca Ricardi ${ }^{1 *}$, Lia Leme Zaia ${ }^{2}$, Ivete Pellegrino Rosa ${ }^{3}$
}

${ }^{1}$ Ex- Post-graduation Program in Clinical Endocrinology, Department of Medicine, Federal University of São Paulo, Brazil

${ }^{2}$ Laboratory of Genetic Psychology, Faculty of Education, State University of Campinas, Campinas, São Paulo, Brazil

${ }^{3}$ Collegiate of Education, Santo André Foundation University Center, Santo André, SP, Brazil
*Corresponding author

Fatima C F Ricardi, Post-graduation Program in Clinical Endocrinology, Department of Medicine, Federal University of São Paulo, São Paulo, Brazil

Submitted: 16 Jun 2021;Accepted: 17 July 2021;Published: 26 July 2021

citation: Fátima do Carmo Fonseca Ricardi, Lia Leme Zaia, Ivete Pellegrino Rosa. (2021). Practical Activities for Cognitive Stimulation of Turner Girls, Teenagers and Women: A Guide for Themselves and their Families. Int J Women's Health Care, 6(3), 197-198.

\section{Objective}

To provide at no cost to parents or guardians of girls or teenagers and to women, all with Turner syndrome:

A. Simple and effective activities (for frequent performance) and without any contraindication, directed towards specific cognitive stimulation.

B. Other useful recommendations.

\section{Activities}

1. For parents or guardians to perform with "Turner" girls or teenagers.

NOTE: the activities can be carried out a few minutes a day or for a longer while, less times a week.

- In order to increase the number of dendrites in brain cells: simple naming of figures or images; reading; word games (for example, word search, crossword puzzles, crooked words, etc.); asking the meaning of words; making connections between words (for example, successive word association games); naming words quickly; writing tasks; making drawings corresponding to words [1].

- For the development of spatial relations: wooden building blocks (Playing Engineer, e.g.); puzzles; figures assembly; geometrical figures fitting; and free drawing [2].

- In order to stimulate the construction of logical structures, provide: memory games (appropriate for each age)2; riddles, logical challenges [4]; reasoning games ("Kalah" [4,5], iGridlock (for iPads), "Connect Four" [4], "Fourth" [6]; "Guess Who" [5]; dominoes; and "Peg Solitaire" or "Solo Noble"); games related to arithmetic operations ("Put and Take" [5]; "Make 10" [5]).

- In order to stimulate causal relationships establishment, provide: "Pick-up-Sticks" (or "Jackstraws", or "Spillikins") game [2]; bowling; "Balance Ice Cubes" (or "Save Penguins", or "Penguin Trap") game [4,7]; "Sjoelback [8]; and "Paper Tower" (or "Team Building") game [5,9].

- In order to provide own body knowledge and mastery: songs with gestures (e.g.: "Hokey- Pokey"); clay doll followed by its drawing [2].

2. For "Turner" girls and women themselves, in order to improve their performance in school activities:

In order to increase their own processing speed [10]:

- $\quad$ Practice a specific skill, trying to improve one own's speed while performing it; this applies to everything: the more you do a task, the faster you get at it [10].

- Try to cut down the time it takes to do a homework assignment, make a list of what is required, as well as one of all the materials needed, for the assignment and work through them step by step [10].

- Cross out each completed step from the lists mentioned in the previous item [11].

- Work on planning and organisation skills, e.g. by estimating how long a project will take and then tracking whether you are on track or whether your plan needs to be adequate [10].

- Break assignments and homework into chunks, breaking down tasks can make them appear more manageable [10].

- Try not to be overwhelmed by the amount of information presented on revision tasks or you might fear they will not get it done, which will aggravate anxiety levels [10].

- Ask for pre-printed notes you can 'pre read' but still take your own notes in class; research shows that writing down new information helps you to remember it.

- Consider using a keyboard rather than writing, for some people with slow processing speed using a computer to take class notes is faster and easier than handwriting.

- On the other hand, practice handwriting - the more you write 
by hand, the faster and clearer note taking will be. In addition, some research has shown that handwriting helps to memorize and process content [12].

- If reading is assigned before a class, make it a priority, this way you will already be familiar with what you are hearing in a lesson. It can help you better understand and become familiar with new words and concepts.

- $\quad$ Review class notes every night, even a quick glance will help pick out spots where information is missing or notes are unclear. The chances are you will be able to fill in the gaps when the information is still fresh.

- Cover all questions but one at a time, focus attention on that one, do not worry about the others until you come to them.

- Use sticky notes and highlighters in active revision.

- $\quad$ Use mind mapping [13] for note taking- reducing the amount of writing.

- Use technology (plus keyboard) for note taking and mind mapping etc. [10].

- Try brain training apps, etc. to try to develop and improve speed of processing.

- Be aware of the emotional factors linked to slow processing. It can all feel too much and this is when you need to stop and ask for help.

Other Useful Recommendations

(for parents or guardians of Turner girls or teenagers):

In order to develop attention and calmness, while performing tasks [11]:

- Provide clear and consistent routines at home and school.

- Keep rules clear and simple, and give reminders calmly.

- Get physically close to the child and make sure you have the child's full attention when you talk.

- Give instructions one or two at a time.

- Supervise closely as the child may put themselves in dangerous situations.

- Try to ignore irritating behaviours.

- Make time for fun and relaxing things for the child to do.

- $\quad$ Provide the child a place to study where there are no distractions.

- Make it clear all the time that you are observing what the child tries to do, her effort, even when she does not do well.

- $\quad$ Retain good communication with doctors and teachers.

\section{References}

1. Jennifer Harasty's (2003) Investigation of the Brain in Turner Syndrome. on the 6th International Turner Syndrome Conference, Sydney, Australia, 10-13.

2. Ricardi FCF, Zaia LL, Pellegrino-Rosa I, Rosa JT, Verreschi ITN (2019) Psychopedagogic intervention according to Piagetian Theory in three girls with Turner syndrome: performance improvement revealed by Bender Test. ARCH Women Health Care 2: 1-8.

3. Papaterra F (2018) Manual Papaterra: livro girafa para treinamento de... raciocínio lógico. Book Toy, Ribeirão Preto 124.

4. Gonçalves EC Intervenção Pedagógica com Jogos Eletrônicos e Concretos na Construção de Estruturas Cognitivas: um estudo Piagetiano. Masters of Science thesis. Marília: Faculdade de Filosofia e Ciências, Universidade Estadual Paulista, Brazil. p. 245. 2020.

5. Zaia LL A Solicitação do Meio e a Construção das Estruturas Operatórias em Crianças com Dificuldades de Aprendizagem. Ph.D. thesis. Campinas: Laboratório de Psicologia Genética (1996) Faculdade de Educação, Universidade Estadual de Campinas, Brazil 255.

6. Macedo L, Petty ALS, Passos NC (2000) Aprender com jogos e situações-problema. Artes Médicas Sul, Porto Alegre 95.

7. Jogo Pinguim Numa Fria ("Quebra Gelo")- Estrela.

8. Jogo Sjoelback (ou bilhar holandês)- Simque Brinquedos Educativos. https://www.youtube.com/watch?v=GQkR5_ZQSuI

9. https://www.youtube.com/watch?v=qcA8Fssfe6g

10. Partly extracted and adapted from Turner Syndrome Support Society (TSSS) education booklet: "Turner Syndrome \& Education. How to support girls with TS to thrive and succeed at school: a guide for parents, carers and teachers": https:// tss.org.uk/downloads/New\%20How\%20to\%20help\%20 your $\% 20$ c hild $\% 20$ thrive $\% 20$ and $\% 20$ succeed $\% 20$ at $\% 20$ school..pdf).

11. Partly extracted and adapted from the printed material distributed during Dr. Mark Brandtman's workshop entitled Ensuring your Daughter's Best Interests/ Learning Difficulties in Turner Syndrome on the 6th International Turner Syndrome Conference, Sydney, Australia, 10-13 July, 2003.

12. Mourão Júnior CA, Faria NC (2015) Memória. Psicol. Reflex. Crit 28: 780-788.

13. Buzan T, Buzan B (1996) The Mind Map Book, Plume, 2. edition, 320p. APUD Keidann GL (2013) Utilização de Mapas Mentais na Inclusão Digital. IN: Educom Sul II, 2013, Ijuí/ RS. Perspectivasteórico-metodológicas 2: 1-15.

Copyright: (C2021 Fatima C F Ricardi, et al. This is an open-access article distributed under the terms of the Creative Commons Attribution License, which permits unrestricted use, distribution, and reproduction in any medium, provided the original author and source are credited. 